\title{
University Students as Composers of a Digital Video
}

\author{
Carita Kiili $^{1}$, Merja Kauppinen ${ }^{2}$, and Leena Laurinen ${ }^{1}$ \\ ${ }^{1}$ Department of Education \\ ${ }^{2}$ Department of Teacher Education \\ P.O. Box 35, FI-40014 University of Jyväskylä, Finland \\ \{carita.kili, merja.a.kauppinen, leena. laurinen\}@jyu.fi
}

\begin{abstract}
This paper introduces a university course in which digital video composing was used as a study method. The aim of the course was to empower future teachers to use digital and multimodal literacy practices in their own teaching. Students in education, 13 in total, participated in the course on digital literacies. The course achievement was measured with the task in which students composed a video in small-groups. The students' videos were supposed to convince a pedagogical target group about the usefulness of a teaching method or need for a reform. In the last meeting, student's videos were watched and the contents of the videos were discussed. The experiences on composing a digital video were also shared. In the last meeting, the students answered to a questionnaire on their experiences on video composing. After the course the students wrote a self-evaluation about their own learning. This paper seeks to clarify students' experiences on learning of multimodal literacy practices, ICT use and course content. Most of the students reported that they learned to create and interpret multimodal texts. New ICT-tools were also learned to use. The study showed that video composing can be used to study content knowledge at the university course.
\end{abstract}

Keywords: digital literacy, digital video composing, multimodal literacy, teacher education.

\section{Introduction}

Future teachers and educational professionals are in an important position when it comes to developing pupils' abilities to make meanings with different digital tools and educating digitally literate citizens. Paul Gilster [1, p. 1] was the first to introduce the term digital literacy by defining it as "the ability to understand and use information in multiple formats from a wide range of sources when it is presented via computers". Later, for example, Martin and Grudziecki [2] have defined digital literacy as awareness, attitude and ability of individuals' to use digital tools for utilizing digital sources, constructing knowledge, creating media expressions, and communicating with others in specific life situations. The sociocultural perspective on digital literacy emphasizes digital literacy as set of various social practices and prefers the use of the plural form "digital literacies" [3]. People engage in diverse digital meaning making practices, such as blogging, twittering, online discussion, to name a few. Additionally, different types of digital texts will themselves take multiple forms 
depending on the purpose of the text [3]. According to Gee [4] digital literacy practices are situational and socially constructed and therefore, they are best learned by participating in meaning-making activities in varying social contexts.

In this article, we concentrate on one digital literacy practice, i.e., composing a digital video, in which purposeful multimodal digital literacies are focused. We will introduce a university course for educational students in which digital video composing was used as a study method. Arranging the course was motivated by the fact that teachers in Finland still use mainly printed texts and individually-oriented literacy methods [5]. We offered students an experience of the composition of a digital video in order to empower them to use multimodal literacy practices in their forthcoming work. This paper examines students' learning experiences on engaging in multimodal literacy practices and using information and communication technology (ICT) as well as learning of the course content on digital literacies. In the present study examples are given of multimodal means that students used in their videos.

\section{$2 \quad$ Multimodal Literacy Practices}

Literacy and literacy education are undergoing many changes. On the Internet and other new media, knowledge is increasingly presented in multimodal forms [6]. Texts combine images, sounds, gestures, and textual elements in complex ways [7], [8]. Thus, people engage in diverse multimodal literacy practices in their free time and work life. This demands flexibility to move across different modes, genres, and discourses [9]. Bearne [6] argues that these changes influence even on that how people think.

Kress [7] illustrates changes in meaning making practices with two shifts. For writers, the change means the shift from telling the world to showing the world. Writers can combine different modalities according to the situation and purpose of the text. They can make choices between different modalities and if necessary also transform knowledge from one modality to another. For readers, the change in meaning making practices means the shift from reading as an interpretation to reading as a design. In traditional texts, the reading order is more or less fixed whereas in multimodal texts readers have to choose in what order they proceed in the text. Thus, readers create their own reading paths.

Composing multimodal texts, such as digital videos, comprise the following four aspects: materiality, framing, design, and production [10], [11]. Materiality refers to the materials and resources (e.g. images, music, concepts) that can be used to make meanings whereas framing refers to how different elements operate together and how they are connected. Design concerns how people use available resources and materials in order to create a representation. Finally, production refers to the creation of a final product (e.g. video, podcast) by using the tools needed.

Recent changes in meaning making practices suggest that a wide spectrum of different kinds of texts should be used in classrooms. However, Luukka and her colleagues [12] found that Finnish teachers in mother tongue and foreign languages use digital texts quite seldom. Reasons for this might be that teachers see literacy in a quite narrow way or they do not feel themselves confident with digital tools [13]. 
Earlier studies have shown that a lack of confidence on own abilities, i.e. low selfefficacy, concerning technological skills is related to teachers' low use of digital tools in their classroom [14], [15].

Experiences on digital video composing might lower future teachers' threshold to use digital and multimodal literacy practices in their own teaching. Digital video composing provides teachers with opportunities to orchestrate visual, auditive, kinesthetic, and textual modes by applying computer software, such as Movie Maker or iMovie [13]. The aim of the present teaching experiment was both to offer knowledge on digital literacies and to provide learning experiences on digital video composing. We studied what kinds of learning experiences educational students had when they studied digital literacies with composing a video.

\section{Methods}

\subsection{Participants}

The course concerning digital literacies was arranged in one Finnish faculty of Education. Students $(\mathrm{n}=13 ; 11$ females and 2 males; 9 teacher students and 4 educational students) who participated in the course, aged from 22 to 43 . The course was taught by two teachers who also acted as researchers.

\subsection{Task}

The course achievement was measured with a task in which the students were asked to compose a digital video, five minutes in duration, in four small-groups with 2-4 students. The students utilized Movie Maker -program in their video composing. They were asked to choose a teaching method or a reform concerning digital literacies and name a pedagogical target group for their video. The purpose of the video was to convince the target group about the usefulness of the teaching method or need for the reform. The students were also asked to include some pedagogical implications into their video. Students' creativity was encouraged.

\subsection{Procedure}

The course consisted of four meetings that contained two lectures on digital literacies. In the beginning of the first lesson, the students answered to a questionnaire on their use of ICT. In the third meeting, the students prepared for video composing after which the student groups composed a traditional short essay as a theoretical background for their digital videos and composed their videos with Movie Maker. In the last meeting, all four videos were watched in the class after which the students discussed how their groups had created meanings in their videos. The students also evaluated how convincing the videos were in the point of view of the target group. Finally, students shared their experiences on learning of multimodal literacy practices. In the end of the last meeting the students answered to a questionnaire on their experiences of video composing. After the course the students wrote a self-evaluation about their learning and group work. 


\subsection{Data Sources and Data Analyses}

The data consisted of the classroom discussion arranged during the last meeting, digital videos $(n=3)$ composed by the groups, students' self-evaluations $(n=11)$ and answers to the questionnaire on their ICT use and on their experiences of video composing $(n=12)$. The questions on students' ICT use contained 19 Likert-scale items (a five point scale ranging from totally agree to totally disagree). The items concerned acquiring information, sharing information, and creating knowledge both in social networks and in public Internet. The questions on students' experiences on video composing contained 17 Likert-scale items. The students were asked to compare video composing with writing a traditional essay (6 items) and to assess what kinds of digital and multimodal literacy practices they learned during the course (11 items).

The duration of videos was about 5 minutes. The topics of the videos were: "Blogs should be used in the literacy class"; "Visual essay"; and "More ICTs to schools". In order to provide examples of how students created meaning in their videos we utilized the framework of multiliteracy provided by The New London Group [8]. It provides a theoretical tool to consider different meaning making modes in multimodal texts. The framework presents the following modes of meaning: linguistic, visual, audio, gestural, and spatial modes. In the framework, multimodality represents the patterns of interconnections among these five modes. The framework also specifies some design elements for each of the modes that can be used to create meanings. For example, elements of audio design include music and sound effects.

From the classroom discussion only those parts, that were relevant to this study (altogether 181 speech turns), were transcripted. From the classroom discussion and self-evaluations we selected examples that best described the students' experiences on learning of multimodal literacy practices, ICT use and course content.

The written consent to all data was sought from the students. One student did not sign the consent; therefore all data related to her was ignored, including the video of her group.

\section{$4 \quad$ Results}

\subsection{ICT Use}

The students reported that they use ICT mainly for searching information and for social networking. They use ICT far less for creating knowledge. Only few students (3) told that they have used digital tools for editing or creating videos. The students also quite seldom share knowledge with others on the Internet.

\subsection{Students' Digital Videos}

Table 1 provides some examples of how the students used different modes of meaning in their videos. The videos included photos, pictures, text, music, and sound effects. Students also acted in their videos (in two of them). The students combined different 
modes of meaning in order to create meanings in a multimodal way. For example, in one video the students had combined linguistic and visual modes when they presented the advantages of blog writing. It was told in the video that blog writing provides opportunities for problem-based learning. The words "problem-based learning", were illustrated with the photo of Rubick's cube. Later in the same video, the narrator, who is sitting in the restaurant, argues: "Blogs can be used wherever".

Table 1. Examples of the use of different modes of meaning in students' videos

\begin{tabular}{|c|c|}
\hline Mode of meaning & Examples \\
\hline Linguistic & $\begin{array}{l}\text { Anagram (HOT=Higher Order Thinking); catch words; the } \\
\text { use of questions as indicators of shifting the topic }\end{array}$ \\
\hline Visual & $\begin{array}{l}\text { Creating contrasts between two learning situations with colors } \\
\text { (black-and-white vs. multicolored); visual metafora (Rubick's } \\
\text { cube indicating problem solving); a question mark in the } \\
\text { middle of the photo to stimulate thinking; zooming to awake } \\
\text { attention }\end{array}$ \\
\hline Audio & $\begin{array}{l}\text { Making contrasts with music (joyful rhythm music vs. } \\
\text { frightening, electronic music out of tune); silent moments as } \\
\text { an effect; music underling a textual message }\end{array}$ \\
\hline Gesture & $\begin{array}{l}\text { Enthusiastic look to pronounce the message; anguished face } \\
\text { mediating difficulties in writing; a smiling teacher is assigning } \\
\text { a visual writing task; an offering hand movement when } \\
\text { introducing a new writing method }\end{array}$ \\
\hline Spatial & $\begin{array}{l}\text { Arranging elements according to their importance; letters } \\
\text { coming one by one upon the screen }\end{array}$ \\
\hline
\end{tabular}

\subsection{Experiences on Learning Multimodal Literacy Practices}

Most of the students (8/12) reported that they learned new multimodal means to create meanings. In Example 1, a student describes how her group combined visual and textual modes of meanings and pondered how these modes interact.

Example 1. The text was always first. Then, the pictures gave some reasons for the text. It was a sort of dialogue between the text and picture. The purpose was to strengthen certain arguments. We stated a question at the beginning. Why? These kinds of short questions are those that one will pay attention to (classroom discussion).

All students, except one, reported that they learned to interpret different modes of meaning during the course. The students told that they learned to see multimodal meanings during composing a digital video but also when they looked and interpreted 
videos composed by other students. The following example from the classroom discussion shows how the students interpreted meanings.

\section{Example 2.}

Mira: Music varied according to the theme or topic. You paid attention to it. You noticed that now it (the theme) really changed.

Anna: Time was left for thinking. I have seen a commercial like this where a similar kind of music was used in order stimulate people to think the very idea (classroom discussion).

According to Sanders and Albers [11], composing a digital video offers opportunities to practice critical reading when students examine material choices, consider how materials are framed and designed, and how these decisions are realized and situated within the composer's beliefs. In Example 3, a student ponders how different modes of meaning were combined for creating stereotypes in the video composed by another student group.

Example 3. It was carried to extremes by using grayness when there was the boring teacher with a monotonous voice. Then there was a lovely, smiling teacher. And with these means the two stereotypes were created (classroom discussion).

The students found discussions of each others' videos useful. When other students analyzed the video they provided new perspectives even for the composers, as reported by one student in Example 4.

Example 4. When we discussed the videos together others noticed ideas from your video that are new to you. Then you realized that so it is (laughing). You have not realized that you have thought quite narrowly the message of your own video. Actually, it includes thousands of messages (classroom discussion).

In general, the students experienced digital video composing as an innovative and social practice. One of the groups told that they learned that digital video composing demands a new kind of collaboration compared to traditional group writing tasks. On the contrary, there was another group who did not work collaboratively but divided the task and responsibilities among four group members. Two students of this group were not satisfied with this co-operative way of working as they experienced that they did not learn enough of multimodal literacy practices.

\subsection{Experiences on Learning ICT Use}

Only few students were familiar with Movie Maker -tool before the course. A little more than half of the students (7/12) reported that during the course they learned to use ICT-tools that were new to them. One of the students commented her experiences on learning the use of Movie Maker in the following way:

Example 5. The most valuable learning experience was the practicing MovieMaker program (self-evaluation). 
Two-thirds of the students experienced that they got more self-confidence in applying ICT. A chance to use new technologies may even affect students' attitudes, as shown below.

Example 6. I could say that that the most important learning experience was the change in my attitudes. A computer is an opportunity not a threat, especially in my future profession as an adult educator (self-evaluation).

Two-thirds of the students thought that they will apply their experience on digital video composing in future. During classroom discussion three students told that they will later use the digital writing method that they introduced in their video.

\subsection{Experiences on Learning Content by Composing a Digital Video}

One of the goals of the course was that students broaden their conception of literacy. This goal was pretty much achieved as $75 \%$ of the students reported that composing a digital video helped them to extend their understanding about literacy. Further, twothirds of the students reported that they learned the course content as well as if they would have written a traditional essay in the course. The students did not experience that the pedagogical concepts were better concretized when composing a digital video compared to composing a traditional essay.

The following Example 7 illustrates how students can consider pedagogical issues when they compose a digital video. In their video, students wanted to discuss how boys in secondary school could be engaged in literacy. They suggested that composing a visual essay could motivate boys to write.

Example 7. We thought recent discussions about writing difficulties of boys in the $9^{\text {th }}$ grade, they cannot write very well. How could we develop their understanding of writing and increase their enthusiasm for writing? When boys can first express their ideas with a video or a picture, they could then accomplish their thoughts by writing (classroom discussion).

When the students watched each others' videos they were able to share their pedagogical ideas, as shown in the following:

Example 8. I liked a lot when you gave few examples how one could use it (blog) in the classroom: storytelling, interviewing one's godmother or godfather or grandparents (classroom discussion).

\section{Discussion}

This study indicated that digital video composing as a study method provided educational students with opportunities to learn multimodal literacy practices, ICT use, and content knowledge on digital literacies. Most of the students reported that experiences on multimodal literacy practices broadened their conception of texts and literacy. This probably means that the students became to understand literacy not only 
as reading and writing linear, traditional texts but also as multimodal, digitally constructed social practice.

Majority of the students experienced that they learned new means to create and interpret different modes of meaning. Composing a digital video may also offer opportunities to become a more critical reader. When the students made their material choices and combined different modes of meaning in order to convince the pedagogical target group with their video, they became more aware of how meanings are embedded into the multimodal texts. They have also learned critical thinking when they talked about meanings included in each others' videos. Gee, Hull and Lankshear [16] stress that a way of reading a certain type of text is acquired only when it is acquired in a "fluent" or "native-like way" by one's being embedded in a social practice in which people also talk about such texts in certain ways, hold certain beliefs and values about them, and socially interact over them. These kinds of personal learning experiences on multimodal literacy practices may increase the possibility that future teachers will integrate multimodal, digital literacy practices in their own teaching and create pedagogies relevant to millennial students. However, working in a co-operative way may hinder opportunities for some students to learn multimodal literacies. If labor is divided in the group so that some group members are only responsible for providing a theoretical background for the video without participating in actual creation of the video, the learning aims concerning multimodal literacies might probably not be achieved.

Previous research among university students [17], [18] have shown that students use information and communication technology mainly for searching information and for social networking. In contrast, technology is less used for creating knowledge. In line with these results, only few students, who participated in the present study, had previous experiences on digital video composing. Many of the students experienced that they learned to use new ICT tools, and especially tools that can be applied for creating knowledge. Further, two-thirds of the students experienced that they got more self-confidence in applying ICT. The increase in self-confidence may lower teachers' threshold to use digital and multimodal literacy practices in their own teaching. Actually, two-thirds of the students reported that they could utilize the experiences on digital video composing in their future work. However, the fact that the course was part of optional studies might partly explain students' positive attitude towards implementing digital video composing in their class. It might be that the course was chosen only by those students who do not resist the use of ICT in teaching.

This study showed that digital video composing can be used to study content knowledge at the university course. The students reported that they learned the course content as well as if they had composed a traditional essay as a course assignment. One reason for this might be that in the course the traditional essay writing (a short background paper for a digital video) was combined with composing the video. This ensured that the students also familiarized themselves with relevant educational literature.

Although this study was based only on self-reported data it showed some potential benefits of using digital video composing as a study method in teacher education. 
When students gain hands-on experiences on digital video composing they become more self-confident in using ICT tools in their own teaching. They learn to create meanings through combining different modalities and to ponder how meanings are made in videos. These learning experiences can be applied, for example, in media education. There is a need for a longer lasting intervention that would provide teacher students with experiences on creating knowledge with varying digital tools. A longer intervention would offer opportunities to measure intervention effects on students' self-efficacy and later use of ICT in the classroom.

\section{References}

1. Gilster, P.: Digital literacy. Wiley Computer Pub., New York (1997)

2. Martin, A., Grudziecki, J.: DigEuLit: Concepts and tools for digital literacy development (2007), http://www.ics.heacademy.ac.uk/italics/vol5iss4/martingrudziecki.pdf

3. Lankshear, C., Knobel, M.: Introduction: Digital literacies - Concepts, policies and practices. In: Lankshear, C., Knobel, M. (eds.) Digital Literacies: Concept, Policies and Practices, pp. 1-16. Peter Lang, New York (2008)

4. Gee, J.P.: A situated-sociocultural approach to literacy and technology. In: Baker, E.A. (ed.) The New Literacies: Multiple Perspectives on Research and Practice, pp. 165-193. The Guildford Press, New York (2010)

5. Taalas, P., Tarnanen, M., Kauppinen, M., Pöyhönen, S.: Media landscapes in school and in free time - two parallel realities? Digital Kompetanse 4(3), 240-256 (2008)

6. Bearne, E.: Rethinking literacy: Communication, representation and text. Reading Literacy and Language 37(3), 98-103 (2003)

7. Kress, G.: Literacy in the new media age. Routledge, London (2003)

8. The New London Group: A pedagogy of multiliteracies: Designing social futures. In: Cope, B., Kalantzis, M. (eds.) Multiliteracies: Literacy Learning and the Design of Social Futures, pp. 9-38. Routledge, London (1996)

9. Stein, P.: Multimodal Instructional Practices. In: Coiro, J., Knobel, M., Lankshear, C., Leu, D.J. (eds.) Handbook of Research on New Literacies, pp. 871-898. Erlbaum, Mahwah (2008)

10. Kress, G., Jewitt, C.: Introduction. In: Jewitt, C., Kress, G. (eds.) Multimodal Literacy, pp. 1-18. Peter Lang, New York (2003)

11. Sanders, J., Albers, P.: Multimodal literacies: An introduction. In: Albers, P., Sanders, J. (eds.) Literacies, the Arts \& Multimodalities, pp. 1-24. National Council of Teachers of English, Urbana (2010)

12. Luukka, M.-R., Pöyhönen, S., Huhta, A., Taalas, P., Tarnanen, M., Keränen, A.: Maailma muuttuu - mitä tekee koulu? In: Äidinkielen Ja Vieraiden Kielten Tekstikäytänteet Koulussa Ja Vapaa-Ajalla. Soveltavan kielentutkimuksen keskus, Jyväskylän yliopisto (2008)

13. Miller, S.M.: English teacher learning for new times: Digital video composing as multimodal literacy practice. English Education 40(1), 61-83 (2007)

14. Van Acker, F., van Buuren, H., Kreijns, K., Vermeulen, M.: Why teachers use digital learning materials: The role of self-efficacy, subjective norm and attitude. Education and Information Technologies (2011), doi:10.1007/s10639-011-9181-9 
15. Albion, P.R.: Self-efficacy beliefs as an indicator of teachers' preparedness for teaching with technology. In: Technology and Teacher Education Annual 1999, Association for the Advancement of Computing in Education, Charlottesville (1999), http://eprints.usq.edu.au/6973/1/Albion_SITE_1999_AV.pdf

16. Gee, J.P., Hull, G., Lankshear, C.: The new work order: Behind the language of the new capitalism. Westview Press, Boulder (1996)

17. Kennedy, G., Judd, T., Dalgarno, B., Waycott, J.: Beyond natives and immigrants: Exploring types of net generation students. Journal of Computer Assisted Learning 26(5), 332-343 (2010)

18. Oliver, B., Goerke, V.: Australian undergraduates' use and ownership of emerging technologies: Implications and opportunities for creating engaging learning experiences for the net generation. Australasian Journal of Educational Technology 23(2), 171-186 (2007) 